\title{
Bird Functional Diversity in Agroecosystems and Secondary Forests of the Tropical Andes
}

\author{
Vanessa Velásquez-Trujillo ${ }^{1}$ (D) Juan F. Betancurt-Grisales ${ }^{1}$ (D), Angela M. Vargas-Daza ${ }^{1}$, Carlos E. Lara ${ }^{2}{ }^{(D)}$, \\ Fredy A. Rivera-Páez ${ }^{3 \oplus}$, Francisco E. Fontúrbel ${ }^{4}{ }^{\circledR}$ and Gabriel J. Castaño-Villa ${ }^{5, *}$ \\ 1 Grupo de Investigación en Ecosistemas Tropicales, Facultad de Ciencias Exactas y Naturales, Universidad de \\ Caldas, Manizales 170004, Colombia; vanevtruji@gmail.com (V.V.-T.); jufebegri@gmail.com (J.F.B.-G.); \\ angela.vargas3093@gmail.com (A.M.V.-D.) \\ 2 Dirección Académica, Escuela de Pregrados, Universidad Nacional de Colombia Sede de La Paz, \\ La Paz 200001, Colombia; celarav@unal.edu.co \\ 3 Grupo de Investigación (GEBIOME), Departamento de Ciencias Biológicas, Facultad de Ciencias Exactas y \\ Naturales, Universidad de Caldas, Manizales 170004, Colombia; fredy.rivera@ucaldas.edu.co \\ 4 Instituto de Biología, Facultad de Ciencias, Pontificia Universidad Católica de Valparaíso, \\ Valparaíso 2373223, Chile; fonturbel@gmail.com \\ 5 Grupo de Investigación (GEBIOME), Departamento de Desarrollo Rural y Recursos Naturales, Facultad de \\ Ciencias Agropecuarias, Universidad de Caldas, Manizales 170004, Colombia \\ * Correspondence: gabriel.castano_v@ucaldas.edu.co
}

check for updates

Citation: Velásquez-Trujillo, V.; Betancurt-Grisales, J.F.; Vargas-Daza, A.M.; Lara, C.E.; Rivera-Páez, F.A.; Fontúrbel, F.E.; Castaño-Villa, G.J. Bird Functional Diversity in Agroecosystems and Secondary Forests of the Tropical Andes. Diversity 2021, 13, 493. https:// doi.org/10.3390/d13100493

Academic Editor: Luc Legal

Received: 15 September 2021

Accepted: 6 October 2021

Published: 9 October 2021

Publisher's Note: MDPI stays neutral with regard to jurisdictional claims in published maps and institutional affiliations.

Copyright: (c) 2021 by the authors. Licensee MDPI, Basel, Switzerland. This article is an open access article distributed under the terms and conditions of the Creative Commons Attribution (CC BY) license (https:// creativecommons.org/licenses/by/ $4.0 /)$.

\begin{abstract}
Agricultural systems have increased in extension and intensity worldwide, altering vertebrate functional diversity, ecosystem functioning, and ecosystemic services. However, the effects of open monoculture crops on bird functional diversity remain little explored, particularly in highly biodiverse regions such as the tropical Andes. We aim to assess the functional diversity differences of bird guilds between monoculture crops (coffee, cocoa, and citrus) and secondary forests. We use four functional diversity indices (Rao Q, Functional Richness, Functional Evenness, and Functional Divergence) related to relevant morphological, life history, and behavioral traits. We find significant differences in functional diversity between agroecosystem and forest habitats. Particularly, bird functional diversity is quite homogeneous among crop types. Functional traits related to locomotion (body weight, wing-chord length, and tail length), nest type (closed), and foraging strata (canopy and understory) are dominant at the agroecosystems. The bird assemblages found at the agroecosystems are more homogeneous in terms of functional diversity than those found at the secondary forests, as a result of crop structure and management. We recommend promoting more diverse agroecosystems to enhance bird functional diversity and reduce their effects on biodiversity.
\end{abstract}

Keywords: agriculture; ecological intensification; environmental filters; functional traits; monoculture crops

\section{Introduction}

The exponential growth of the human population has resulted in a rapid expansion of the agricultural frontier. The transformation from natural habitats to agricultural fields is one of the most common land-use changes [1]. Thus, agricultural intensification has become one of the main biodiversity threats worldwide [2,3]. Given the current land-use change trends, this situation may become critical by 2050, as agricultural fields are expected to globally increase by $70 \%[1,4]$. Such a massive increase in agricultural areas would lead to biodiversity changes, biological homogenization, and the loss of functional diversity and ecosystemic services [5-7].

Coffee, cocoa, and citrus crops cover large land extensions in the tropical region, overlapping with biodiversity hotspots and conservation priority areas [8]. Those crops cover about 20 million ha and are important for the local economies of several developing countries [9-11]. The demand of coffee, cocoa, and citrus is expected to continue increasing 
in the next year, leading to an agricultural intensification at the expenses of natural areas and their biodiversity [12-14]. Land-use change is known to reduce species richness and functional diversity of many vertebrate species [15-17]. Likewise, agricultural intensification (and particularly open monoculture crops) not only change bird species richness and composition, but also their functional diversity $[18,19]$. Those agroecosystems are usually dominated by generalist species, sharing similar functional traits (e.g., diet or body size; [7]) Nevertheless, our knowledge about bird functional diversity in intensive agroecosystems is rather scarce, despite being common in megadiverse countries (e.g., Brazil, Colombia, or Vietnam).

The effects of land-use change and agricultural intensification on biodiversity are usually assessed using species richness and abundance as proxies, but assessing functional diversity may provide a more comprehensive and robust framework for this purpose [20,21] Functional diversity is an integrative concept that considers the different roles that species play within a given community $[22,23]$ and their relationship with ecosystemic services via certain traits [24-26]. Hence, the effects of agroecosystems on biodiversity can be better quantified from the functional diversity perspective.

The Colombian Andes are a good example of land-use change and agricultural intensification, despite being one of the most diverse countries in the world [27]. This region has a long history of deforestation and land-use change, resulting in high levels of habitat fragmentation [28]. The extant native forest remnants are intertwined among productive lands, forestry plantations (of both native and exotic tree species), and degraded lands [29]. Thus, habitat disturbance along the Colombian Andes has changed bird species richness and abundance, with noticeable impacts on highly specialized groups, such as the understory insectivore birds $[29,30]$. Differences in habitat structure and vegetation composition impose environmental filters that favor some species over others, leading to dissimilar communities $[30,31]$. A recent study on this area has compared bird functional diversity between secondary and restored native forests [31], but to the best of our knowledge it has not been assessed on birds from productive lands. In this regard, coffee, cocoa, and citrus crops occupy a large altitudinal range in some areas, such as the Caldas region, harboring 923 bird species [32]. As usual, those crops are established by replacing and fragmenting native forests [33]. In this context, we assessed the effects of agroecosystems on bird functional diversity and bird functional trait composition, aiming to: (1) compare the functional diversity of traits between agroecosystems and native forests using four functional diversity metrics, and (2) determine which functional traits explain the functional diversity differences between agroecosystems and native forests. As agroecosystems have a lower structural complexity than native forests and because functional diversity responds to vegetation structure [31,34], we hypothesize that birds in agroecosystems would have a lower functional diversity with a reduced set of dominant traits determined by environmental filters.

\section{Materials and Methods}

\subsection{Study Area}

This study was conducted in the Central and Western Andes and in the inter-Andean valleys of the Cauca and Magdalena rivers (Caldas department, Colombia; $6^{\circ} 5.4^{\prime} \mathrm{N}$ $75^{\circ} 36^{\prime} \mathrm{W}$ ). The Caldas department has an extension of $7457 \mathrm{~km}^{2}$ [35], from which $69.3 \%$ is covered with seasonal and permanent crop fields, while $21.9 \%$ is covered by natural forests or reforestations. In this area, we sampled five sun coffee (Coffea arabica L.) crops, four citrus (Citrus spp.) crops, six cocoa (Theobroma cocoa L.) crops, and nine secondary native forest patches (Figure S1). These sampling sites are located between 204 and $1829 \mathrm{~m}$ of elevation. The study area has a mean annual precipitation of $2800 \mathrm{~mm}$ and a mean temperature ranging from 17.0 to $24.5^{\circ} \mathrm{C}[36,37]$. 


\subsection{Bird Sampling}

We assessed the avifauna associated with the three agroecosystems and the secondary forests between October 2015 and April 2019. We deployed mist-nets at each habitat type [38,39]. We have chosen this approach because it allows us to register bird species that are usually difficult to detect using other methods (e.g., point-counts) and also allows us to capture the individuals to obtain morphological measurements [31,40,41]. The method used was previously validated in the study area by Castaño-Villa et al. [29]. We had a total of 112 mist-net points: 28 at the coffee crops, 29 at the cocoa crops, 21 at the citrus crops, and 34 at the secondary forests. At each sampling point we installed a mist-net $(12 \times 2.5 \mathrm{~m} \times 36 \mathrm{~mm})$, which was deployed between 10 and $50 \mathrm{~h}$, and operated between 1 and 5 consecutive days, depending on the weather conditions. Capturing points were randomly located within each habitat and operated between 0600 and $1730 \mathrm{~h}$. Overall sampling effort at each agroecosystem was 1000 mist-net-h (making a total of 3000 mistnet-h at the agroecosystems) and at the secondary forests was 1080 mist-net-h. To avoid counting the same individual more than once, captured individuals were marked with a small clip on the first feather of the rectrix. Bird taxonomy followed Remsen et al. [42]. The abundance estimations used for data analysis purposes correspond to relative abundances estimated on the individuals captured at the study area.

\subsection{Bird Functional Traits}

We used morphological, life history, and behavioral traits to assess functional diversity at the sampled habitats, as those sets of traits are known to be functionally relevant as they impact bird growth, reproduction, and survival, as well as affect ecosystem functioning [6,15,43]. We measured seven morphological traits following [44]: bill depth (BD), bill width (BW), total culmen (TC), wing chord length (WC), tarsus length (Ta), tail length (T), and body mass (W); all measurements were measured in mm except for body mass, which was measured in $\mathrm{g}$. We measured these traits in situ before releasing captured individuals using a caliper $\left(0.2 \mathrm{~mm}\right.$ precision) and a Pesola ${ }^{\circledR}$ scale $(0.5 \mathrm{~g}$ precision). We complemented our field data with information from the data paper of Cardona et al. [44] and measurements of specimens deposited at the ornithological collection of the Instituto de Ciencias Naturales, Universidad Nacional de Colombia. Information on life history and behavioral traits was obtained from the published literature $[45,46]$. The life history traits (categorical) included were: (1) diet: frugivore (Fr), granivore (Gr), insectivore (In), or nectarivore ( $\mathrm{Ne})$; and (2) nest type: cup ( $\mathrm{Cu}$ ), enclosed (En), hole (Ho), or platform (Pl). The behavioral traits (categorical) included were: (1) foraging strata: canopy (Ca), sub-canopy (Sca), understory (Un), or ground (Grf); (2) foraging strategy: flower visitor (Fv), searcher $(\mathrm{Ru})$, catcher $(\mathrm{Tr})$, or robber (Th); and (3) habitat type: forest interior (F), forest edge (FE), or open areas (Os). The complete functional trait matrix for the bird species included in our analyses is presented in Table S1.

\subsection{Data Analysis}

\subsubsection{Functional Diversity Analysis}

We estimated functional diversity metrics based upon quantitative data. Therefore, we had to previously transform binomial (i.e., present or absent) life history and behavioral traits into Spearman rank correlation coefficients [47], following the methodology described by Pillar and Duarte [48] and Pillar et al. [49]. Then, to assess bird functional diversity, we grouped our data in two matrices in order to assess bird functional diversity: the $Q$ matrix containing functional traits for each species, and the L matrix containing species-relative abundance at each capturing point. With those matrices we estimated four complementary functional diversity indices: Rao's $Q$ (RaoQ), functional richness (FRic), functional evenness (FEve), and functional divergence (FDiv).

RaoQ index is calculated as the sum of the differences of weighted traits and represents the mean distance of a given trait between two randomly selected individuals [50]. FRic index represents the amount of functional space occupied by a subset of species within the 
community [51]; high FRic values indicate that several niches are occupied by species from the community, while low FRic values indicate otherwise [52]. The FEve index represents the regularity of species abundance distributions along the functional volume [53]; high FEve values indicate that niches are evenly occupied, while low values indicate niche sub-utilization [52]. The FDiv index describes patterns of niche differentiation within the community [51]; high FDiv values indicate a high niche differentiation within the community, and low FDiv values indicate low niche differentiation [52]. We used the FD package [54] in R 3.6.1 [55] to estimate the functional diversity indices. We used the Box-Cox transformation [56] to normalize the functional diversity values obtained from those indices.

To assess the differences in functional diversity (i.e., RaoQ, FRic, FEve, and FDiv) across the three agroecosystem types and the secondary forests, we fitted generalized linear mixed-effects models (GLMMs, hereafter) with a Gaussian error distribution. The response variable was the functional diversity indices obtained (note that we fitted separate GLMMs for each functional diversity index and each functional trait type). We only included habitat type (categorical variable) as a fixed effect, and mist-netting points were included as a random effect. To fit the GLMMs, we used the lme4 package [57], and all the graphs were produced using the ggplot2 [58]; both packages were implemented in R 3.6.1 [55].

\subsubsection{Functional Composition Analysis}

To determine which functional traits were dominant at the agroecosystems, we estimated the community weighted means (CWM) of the measured traits. We calculated CWM values by multiplying the $\mathrm{L}$ and $\mathrm{Q}$ matrices $(\mathrm{L} \times \mathrm{Q}=\mathrm{T})$, where $\mathrm{T}$ represented the mean of each trait weighted by the relative abundance of the species [49]. Then, we represented those CWM values using a principal component analysis (PCA), which was conducted using the R packages SYNCSA [59] and ggplot2 [58].

\section{Results}

We recorded a total of 175 bird species: 76 at the coffee crops (corresponding to 383 individuals), 84 at the cocoa crops (413 individuals), 91 at the citrus crops (663 individuals), and 96 at the secondary forests (334 individuals).

\subsection{Functional Diversity}

Based on the morphological, life history, and behavioral traits of those species, we estimated functional diversity differences among habitats using the four indices chosen for this purpose (Figure 1; see details on Tables S2 and S3). These functional diversity indices showed contrasting results among functional trait groups, as they measured different aspects of functional diversity. We found no difference in morphological traits using Rao's $\mathrm{Q}$ index (Figure 1A), but we found significant difference for life history and behavioral traits among all habitat types (Figure 1B,C). A similar result was obtained using the functional richness (FRic) index, with significant differences between citrus crops and secondary forests for the morphological traits (Figure 1D), and also significant differences for life history and behavioral traits (Figure 1E,F). When examining functional evenness (FEve), morphological and behavioral traits had no significant differences between habitats (Figure 1G,I), but life history traits presented some differences (Figure 1H). Finally, when examining the functional divergence (FDiv), we found significant differences for all functional trait categories (Figure 1J-L), secondary forests being different from all agroecosystems, but functional differences among crops were non-significant in most cases. 
MORPHOLOGICAL

A

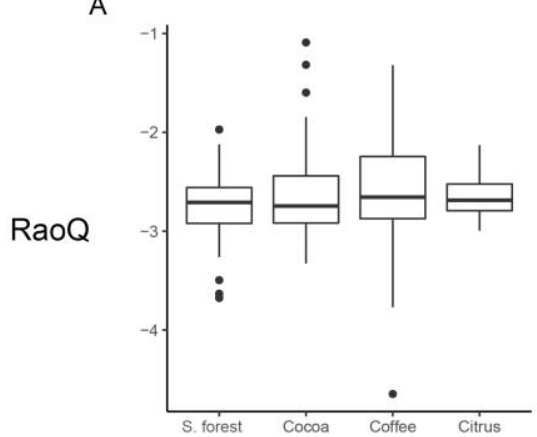

D

FRic

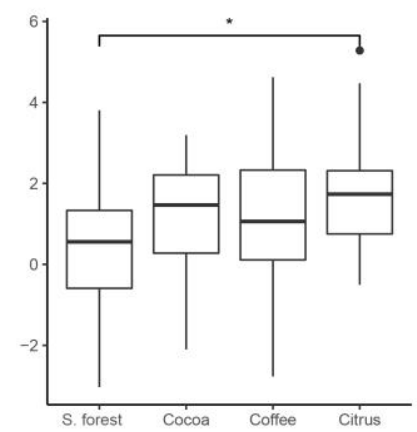

G

FEve

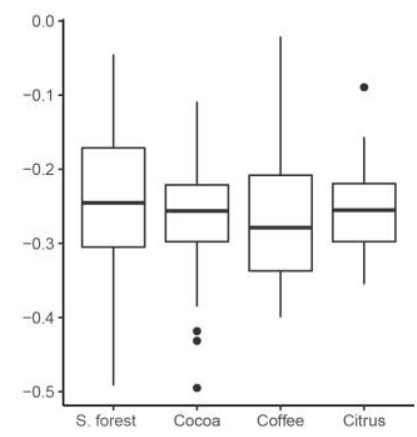

J

FDiv

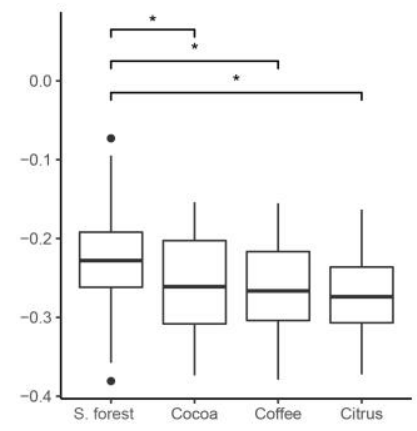

LIFE HISTORY

B

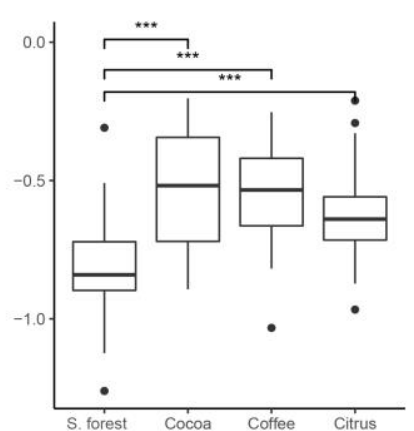

E

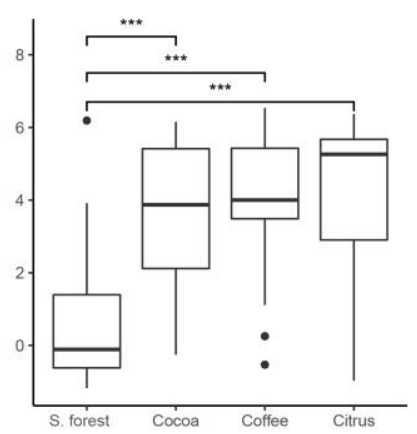

$\mathrm{H}$

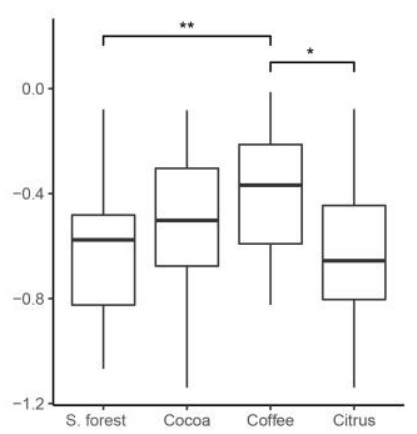

K

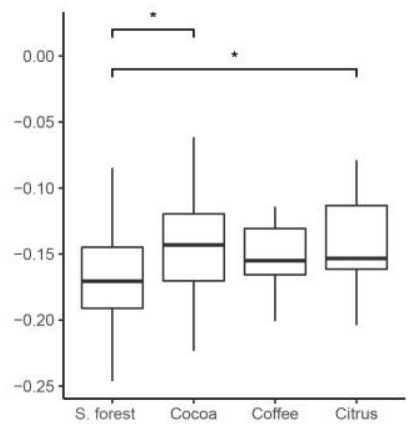

BEHAVIORAL

C

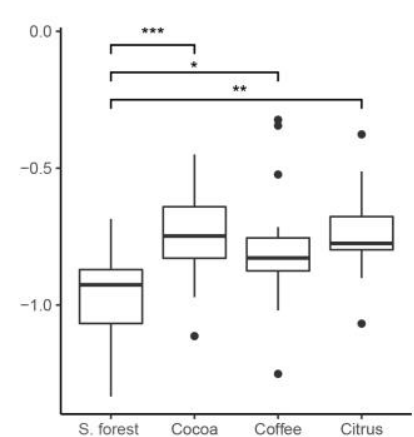

$\mathrm{F}$

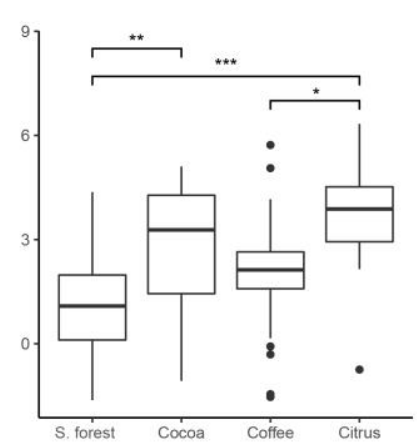

।

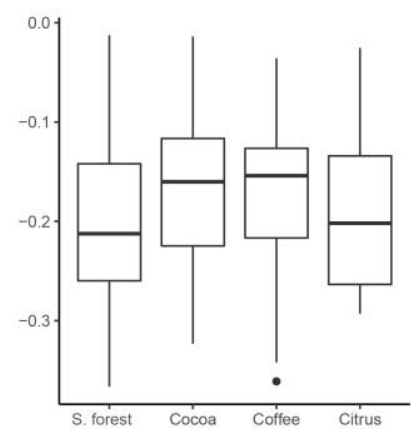

L

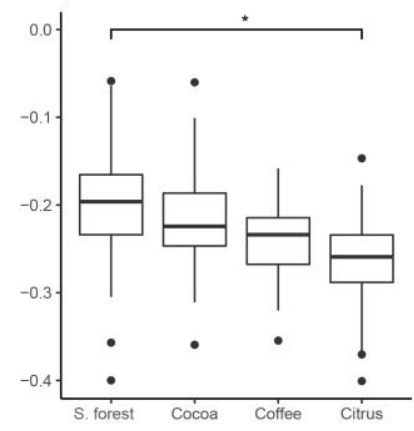

Figure 1. Functional diversity of bird morphological (panels $\mathbf{A}, \mathbf{D}, \mathbf{G}, \mathbf{J})$ ), life history $(\mathbf{B}, \mathbf{E}, \mathbf{H}, \mathbf{K})$, and behavioral (panels $\mathbf{C}, \mathbf{F}, \mathbf{I}, \mathbf{L})$ traits among agroecosystems and secondary forests using four functional diversity indices: RaoQ (panels A-C), FRic (panels D-F), FEve (panels G-I), and FDiv (panels J-L). Dots outside boxplots represent outlier values. Significant differences are denoted with asterisks $\left({ }^{*} p<0.05 ;{ }^{* *} p<0.01 ;{ }^{* * *} p<0.001\right)$.

\subsection{Functional Composition}

Regarding the morphological traits included in the analysis, the first two PCA axis explained $74 \%$ of the variance (Figure $2 \mathrm{~A}$ ). From these, the dominant traits within the three agroecosystems (explained by the first PCA component) were related to locomotion and dispersal ability (i.e., body mass, wing chord length, and tail length). Conversely, the 
dominant traits at the secondary forests (explained by the second PCA component) were related to foraging (i.e., total culmen, and bill height and width). Regarding life history traits, the first two PCA axis explained $54 \%$ of the variance (Figure $2 B$ ). From those, the dominant traits at the secondary forests (explained by the first PCA component) were related to the diet (i.e., insectivore and frugivore) and nest type (hole nest), while the only dominant trait at the agroecosystems (explained by the second PCA component) was nest type (enclosed nest). Regarding behavioral traits, the first two PCA axes explained $58 \%$ of the variance (Figure 2C). From those, the dominant behavioral traits at the agroecosystems were related to foraging strata (i.e., canopy and ground), foraging strategy (catchers), and habitat type (i.e., forest interior, forest edge, and open areas). Conversely, the dominant behavioral traits at the secondary forest agroecosystems (explained by the second PCA component) were only related to foraging strategies (i.e., searchers and flower visitors).
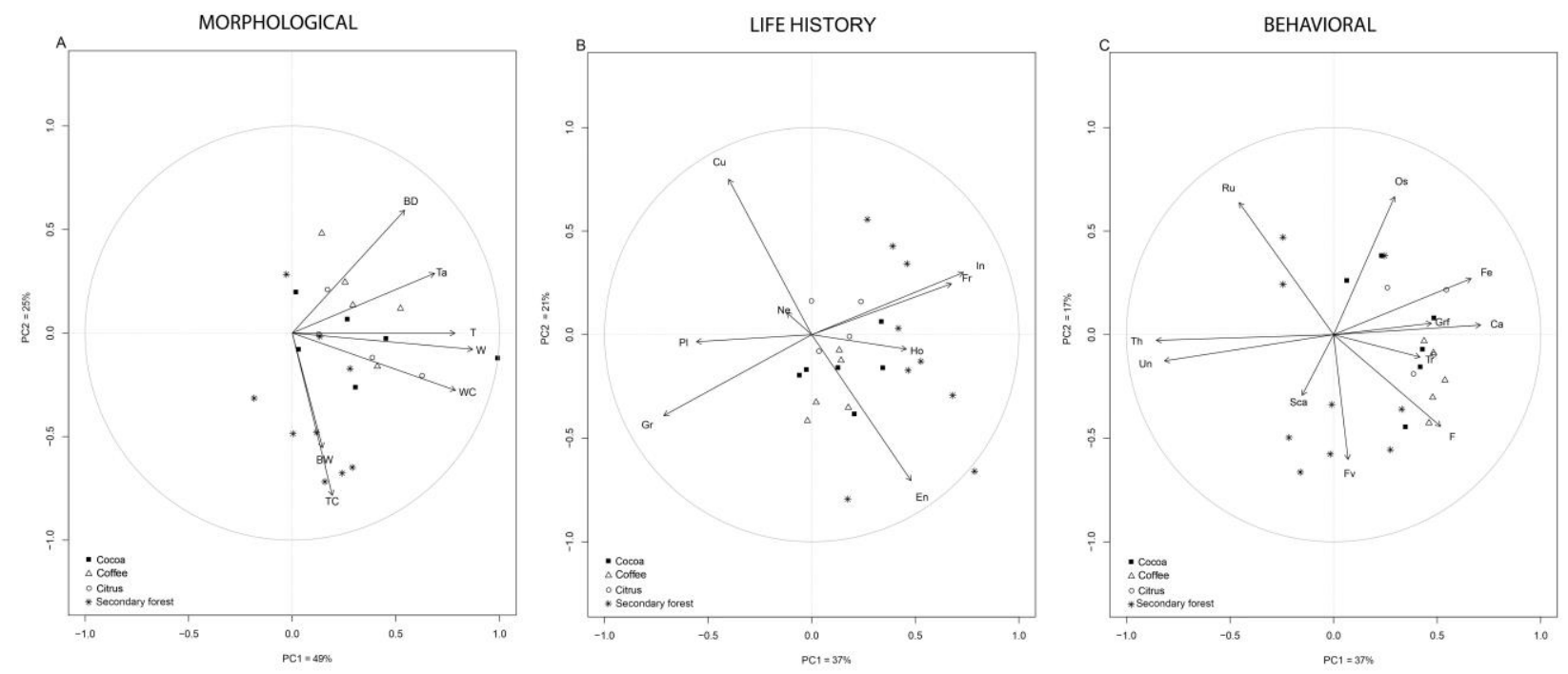

Figure 2. Relationships among functional diversity trait groups for birds in agroecosystems and secondary forests. These results are based on principal component analyses using the community weighted mean on (A) morphological traits, (B) life history traits, and (C) behavioral traits. Trait abbreviations are: BD: bill depth, Ta: tarsus length, T: tail length, W: weight, WC: wing chord, BW: bill width, TC: total culmination, Fr: frugivore, Gr: granivore, In: insectivorous, Ne: nectarivore, Cu: cup, En: enclosed, Ho: hole, Pl: platform, Ca: canopy, Sca: sub-canopy, Un: underbrush, Grf: ground, Fv: flower-visiting, Ru: rummage, Tr: trapper, Th: thief, F: forest, FE: forest edge, Os: open site.

\section{Discussion}

Our results showed that bird functional diversity among the different agroecosystems assessed was similar in most cases, but significantly differed from secondary forests. Therefore, intensive cultivation can lead to a biological homogenization of the functional traits of associated fauna. These findings support the hypothesis that land-use change impacts community-assemblage processes [60]. Furthermore, the dominant functional traits on agroecosystems may be the result of different environmental filters exerted by those habitats, also impacting ecosystem function when we look at the big picture.

\subsection{Functional Diversity}

According to our functional diversity metrics, agroecosystems have larger functional diversity values (in terms of RaoQ and functional richness) than secondary forests. This result agrees with the results of Morelli, Benedetti, Perna and Santolini [60], but contrasts with many other studies $[6,31,61-64]$. Such differences may be due to community characteristics (e.g., species richness and abundance) or to environmental filters related to vegetation structure and landscape heterogeneity. Our results suggest that bird communities associated with different agroecosystems are more similar among each other than to those from secondary forests, due to trait differentiation. Thus, bird communities at 
the different agroecosystems use a larger portion of the functional space. This may be related to the wider resource availability and diversity that birds use at those agroecosystems $[7,51,65,66]$. In this sense, the resources that agroecosystems offer may be allowing more diversity of diets and habitat preferences, which may favor several life history and behavioral traits $[43,67]$. On the contrary, the birds from secondary habitats are restricted to a single habitat type (i.e., we found forest species such as Veniliornis kirkii, Poliocrania exsul, or Ceratopipra erythrocephala, which are absent at the agroecosystems), or those specialized to an insectivore diet (common in the Thamnophilidae, Furnaridae, and Tyrannidae families). Therefore, the presence or absence of specialist species may lead to significant functional diversity differences [68]. On the other hand, environmental heterogeneity may explain some functional differences found among the contrasting agroecosystems [69].

Coffee crops presented higher functional evenness values, as previously reported by Edwards et al. [70] and Davies et al. [71]. Such patterns may emerge from differences in resource-use effectiveness or habitat disturbance. Thus, our results suggest that coffee crops have a larger functional uniformity and more regular spacing within the functional space, compared to citrus crops or to the secondary forests. Particularly, those bird species present at the coffee crops have similar abundances and foraging strategies than those from citrus crops [72]. Most of the bird species found at the coffee crops are insectivores (e.g., Crotophaga ani, Myiarchus cephalotes, and Polioptila plumbea), suggesting that coffee plants are providing insects, and not fruits, as feeding resources [51,73,74]. Contrarily, bird species present at citrus crops and secondary forests showed less functional uniformity. Those bird species fed on insects, fruits, seeds, or nectar (e.g., Amazilia tzacatl, Euphonia laniirostris, or Tiaris olivaceus). Therefore, sun coffee crops tend to homogenize the Andean landscapes, homogenizing the resources that birds use, and consequently homogenizing bird functional traits as well [73,74].

Our functional divergence results showed a constant pattern across habitats. While functional divergence on morphological and behavioral traits was larger at the secondary forests than at the agroecosystems, life history trait functional divergence was larger at the cocoa and citrus crops. These results are similar to those from Morelli et al. [60], Rocha et al. [68], García-Navas, and Thuiller [75]. Hence, those habitats with large functional divergence values suggest high niche differentiation in the dominant species [51], which is likely to affect competition interactions among them [72,75]. In our study sites, the most abundant species were searchers foraging at lower vegetation strata, having similar feeding and locomotion traits (i.e., bill shape and wing length).

\subsection{Functional Composition}

The functional traits that explain morphological variation on agroecosystems (i.e., body mass, wing chord length, and tail length) are related to movement and dispersal capabilities, which are susceptible to be affected by the environmental filters imposed by vegetation physiognomy and planted species density [34]. In this regard, vegetation structure at coffee (e.g., crops with high foliar density and densely planted) and cocoa (e.g., 4-m round-crown trees with thick branches) crops may be determining bird morphology [76,77]. For example, some species forage at the shrubs' foliage, while other forage or perch on the trees' crowns (e.g., Uranomitra franciae, Phyllomyias griseiceps, Basileuterus rufifrons, Momotus aequatorialis, Milvago chimachima, or Pionus menstruus). The dominant life history trait at the agroecosystems is the enclosed nest, which might be reducing egg and chick exposure to predators $[78,79]$. Also, agroecosystems present a combination of bird species with different habitat preferences, but some of them are occasionally found at native forests as well (e.g., Mionectes olivaceus, Pheugopedius sclateri, or Saltator atripennis). Those species may be using agroecosystems as corridors to move among native forest patches [80].

However, our results highlight the dominance of functional traits related to the type of resource consumed at the secondary forests (i.e., total culmen, and bill width and height) and hole nesting habits. Thus, morphological trait variation seems to be closely related to resource availability on forest patches [81]. While hole-nesting seems to be a dominant 
trait in the tropical forests, it depends on the existence of tree cavities. Therefore, holes in old trees may be a critical resource for hole-nester birds [31,53], but those holes are very scarce in disturbed forests and productive lands, where old trees are merely absent.

\section{Conclusions}

Our results suggest that agroecosystems of intensive production can provoke biological homogenization on bird functional diversity, which may drastically alter ecosystem functioning. As the Andean tropical forests are a biodiversity hotspot, the functional diversity homogenization impinged by productive lands can be a major threat to their biodiversity and the ecosystem services that it provides to the local communities. We encourage producers to embrace environmental-friendly practices, such as ecological intensification [82-84], to reconcile production needs with biodiversity. In this regard, including functional diversity analyses in this discussion allows us to go beyond species while quantifying the actual impacts of agroecosystems on biodiversity.

Supplementary Materials: The following are available online at https:/ / www.mdpi.com/article / 10.3390/d13100493/s1, Figure S1: Geographic location of sampling sites, Table S1: Functional traits of bird species Table S2: Mean values of the functional diversity indices, Table S3: Results of the generalized linear models comparing morphological, life history, and behavioral traits among agroecosystems and secondary forests.

Author Contributions: Conceptualization, V.V.-T., J.F.B.-G., A.M.V.-D., F.A.R.-P. and G.J.C.-V.; methodology, V.V.-T., J.F.B.-G., A.M.V.-D., C.E.L. and G.J.C.-V.; formal analysis, V.V.-T., J.F.B.-G., A.M.V.-D. and C.E.L.; investigation, V.V.-T., J.F.B.-G., A.M.V.-D. and G.J.C.-V.; data curation, V.V.-T.; writingoriginal draft preparation, V.V.-T., F.E.F., J.F.B.-G., A.M.V.-D., C.E.L. and G.J.C.-V.; writing-review and editing, V.V.-T., F.E.F., J.F.B.-G., A.M.V.-D. and G.J.C.-V.; visualization, V.V.-T. and J.F.B.-G.; supervision, G.J.C.-V.; project administration, G.J.C.-V. and F.A.R.-P.; funding acquisition, G.J.C.-V. and F.A.R.-P. All authors have read and agreed to the published version of the manuscript.

Funding: This research was funded by the Vicerrectoría de Investigación y Postgrados of the Universidad de Caldas-VIPUCa (grant 0311321). Part of the information included was collected with funding from VIPUCa (grants 0627416 and 0180617).

Institutional Review Board Statement: This research was conducted under the regulations of wildlife specimens and biodiversity use for scientific purposes act, Permit ANLA (Colombia) No. 1166.

Informed Consent Statement: Not applicable.

Data Availability Statement: Data is contained within the article or supplementary material. The data presented in this study are available in Table S1.

Acknowledgments: We are grateful to A. Cuervo (Colección Ornitológica del ICN-Universidad Nacional de Colombia), E. Martínez-Sánchez, M. Bohada-Murillo, and D. Molina-Marín (Grupos de Investigación de Ecosistemas Tropicales) for their collaboration. FEF was supported by project ANID/PIA/ACT192027.

Conflicts of Interest: The authors declare no conflict of interest. The funders had no role in the design of the study; in the collection, analyses, or interpretation of data; in the writing of the manuscript, or in the decision to publish the results.

\footnotetext{
Abbreviations

RaoQ $=$ Rao's $Q$ index, FRic $=$ functional richness, $F E v e=$ functional eveness, FDiv $=$ functional divergence.
} 


\section{References}

1. Barral, M.P.; Benayas, J.M.R.; Meli, P.; Maceira, N.O. Quantifying the impacts of ecological restoration on biodiversity and ecosystem services in agroecosystems: A global meta-analysis. Agric. Ecosyst. Environ. 2015, 202, 223-231. [CrossRef]

2. Sala, O.E.; Chapin, F.S.; Armesto, J.J.; Berlow, E.; Bloomfield, J.; Dirzo, R.; Huber-Sanwald, E.; Huenneke, L.F.; Jackson, R.B.; Kinzig, A. Global biodiversity scenarios for the year 2100. Science 2000, 287, 1770-1774. [CrossRef] [PubMed]

3. Ellis, J.D.; Evans, J.D.; Pettis, J. Colony losses, managed colony population decline, and Colony Collapse Disorder in the United States. J. Apic. Res. 2010, 49, 134-136. [CrossRef]

4. Tapella, E. Heterogeneidad Social y Valoración Diferencial de Servicios Ecosistémicos. Un abordaje Multi-Actoral en el Oeste de Córdoba (Argentina). Ph.D. Thesis, Universidad Nacional de Córdoba, Córdoba, Argentina, 2012.

5. Kim, J.H.; Park, S.; Kim, S.H.; Kang, K.; Waldman, B.; Lee, M.H.; Yu, M.; Yang, H.; Chung, H.Y.; Lee, E.J. Structural implications of traditional agricultural landscapes on the functional diversity of birds near the Korean Demilitarized Zone. Ecol. Evol. 2020, 10, 12973-12982. [CrossRef] [PubMed]

6. Luck, G.W.; Carter, A.; Smallbone, L. Changes in bird functional diversity across multiple land uses: Interpretations of functional redundancy depend on functional group identity. PLoS ONE 2013, 8, e63671. [CrossRef]

7. Sekercioglu, C.H. Bird functional diversity and ecosystem services in tropical forests, agroforests and agricultural areas. J. Ornithol. 2012, 153, 153-161. [CrossRef]

8. Bohada-Murillo, M.; Castaño-Villa, G.J.; Fontúrbel, F.E. The effects of forestry and agroforestry plantations on bird diversity: A global synthesis. Land Degrad. Dev. 2020, 31, 646-654. [CrossRef]

9. Ancillo, G.; Medina, A. Los Cítricos; Publicacions de la Universitat de València: València, Spain, 2015.

10. Sánchez, V.; Zambrano, J.; Iglesias, C. La Cadena de Valor del Cacao en América Latina y el Caribe; FONTAGRO: Washington, DC, USA, 2019.

11. FAO. FAOSTAT Statistics Database (Updated March 2021); Food and Agriculture Organization of the United Nations: Rome, Italy, 2021.

12. Chain-Guadarrama, A.; Martínez-Salinas, A.; Aristizábal, N.; Ricketts, T.H. Ecosystem services by birds and bees to coffee in a changing climate: A review of coffee berry borer control and pollination. Agric. Ecosyst. Environ. 2019, 280, 53-67. [CrossRef]

13. Lahive, F.; Hadley, P.; Daymond, A.J. The physiological responses of cacao to the environment and the implications for climate change resilience. A review. Agron. Sustain. Dev. 2019, 39, 5. [CrossRef]

14. Zabel, F.; Delzeit, R.; Schneider, J.M.; Seppelt, R.; Mauser, W.; Václavík, T. Global impacts of future cropland expansion and intensification on agricultural markets and biodiversity. Nat. Commun. 2019, 10, 2844. [CrossRef]

15. Flynn, D.F.; Gogol-Prokurat, M.; Nogeire, T.; Molinari, N.; Richers, B.T.; Lin, B.B.; Simpson, N.; Mayfield, M.M.; DeClerck, F. Loss of functional diversity under land use intensification across multiple taxa. Ecol. Lett. 2009, 12, 22-33. [CrossRef] [PubMed]

16. Newbold, T.; Hudson, L.N.; Hill, S.L.L.; Contu, S.; Lysenko, I.; Senior, R.A.; Borger, L.; Bennett, D.J.; Choimes, A.; Collen, B.; et al. Global effects of land use on local terrestrial biodiversity. Nature 2015, 520, 45-50. [CrossRef]

17. Petit, L.J.; Petit, D.R. Evaluating the importance of human-modified lands for neotropical bird conservation. Conserv. Biol. 2003, 17, 687-694. [CrossRef]

18. Clough, Y.; Putra, D.D.; Pitopang, R.; Tscharntke, T. Local and landscape factors determine functional bird diversity in Indonesian cacao agroforestry. Biol. Conserv. 2009, 142, 1032-1041. [CrossRef]

19. Philpott, S.M.; Arendt, W.J.; Armbrecht, I.; Bichier, P.; Diestch, T.V.; Gordon, C.; Greenberg, R.; Perfecto, I.; Reynoso-Santos, R.; Soto-Pinto, L.; et al. Biodiversity Loss in Latin American Coffee Landscapes: Review of the Evidence on Ants, Birds, and Trees. Conserv. Biol. 2008, 22, 1093-1105. [CrossRef]

20. Lavorel, S.; Storkey, J.; Bardgett, R.D.; De Bello, F.; Berg, M.P.; Le Roux, X.; Moretti, M.; Mulder, C.; Pakeman, R.J.; Díaz, S. A novel framework for linking functional diversity of plants with other trophic levels for the quantification of ecosystem services. J. Veg. Sci. 2013, 24, 942-948. [CrossRef]

21. Prescott, G.W.; Gilroy, J.J.; Haugaasen, T.; Uribe, C.A.M.; Foster, W.A.; Edwards, D.P. Reducing the impacts of Neotropical oil palm development on functional diversity. Biol. Conserv. 2016, 197, 139-145. [CrossRef]

22. Magurran, A.E.; Baillie, S.R.; Buckland, S.T.; Dick, J.M.; Elston, D.A.; Scott, E.M.; Smith, R.I.; Somerfield, P.J.; Watt, A.D. Long-term datasets in biodiversity research and monitoring: Assessing change in ecological communities through time. Trends Eeology Evol. 2010, 25, 574-582. [CrossRef]

23. Petchey, O.L.; Hector, A.; Gaston, K.J. How do different measures of functional diversity perform? Ecology 2004, 85, 847-857. [CrossRef]

24. Casanoves, F.; Pla, L.; Di Rienzo, J.A.; Díaz, S. FDiversity: A software package for the integrated analysis of functional diversity. Methods Ecol. Evol. 2011, 2, 233-237. [CrossRef]

25. Chapin, F.S., III; Zavaleta, E.S.; Eviner, V.T.; Naylor, R.L.; Vitousek, P.M.; Reynolds, H.L.; Hooper, D.U.; Lavorel, S.; Sala, O.E.; Hobbie, S.E. Consequences of changing biodiversity. Nature 2000, 405, 234-242. [CrossRef]

26. Suding, K.N.; Lavorel, S.; Chapin Iii, F.; Cornelissen, J.H.; Díaz, S.; Garnier, E.; Goldberg, D.; Hooper, D.U.; Jackson, S.T.; Navas, M.L. Scaling environmental change through the community-level: A trait-based response-and-effect framework for plants. Glob. Chang. Biol. 2008, 14, 1125-1140. [CrossRef]

27. Stattersfield, A.J. Endemic bird areas of the world-Priorities for biodiversity conservation. Bird Life Int. 1998. [CrossRef] 
28. Castaño-Villa, G.J.; Estevez, J.V.; Fontúrbel, F.E. The role of native forest plantations in the conservation of Neotropical birds: The case of the Andean alder. J. Nat. Conserv. 2014, 22, 547-551. [CrossRef]

29. Castaño-Villa, G.J.; Ramos-Valencia, S.A.; Fontúrbel, F.E. Fine-scale habitat structure complexity determines insectivorous bird diversity in a tropical forest. Acta Oecologica 2014, 61, 19-23. [CrossRef]

30. Castaño-Villa, G.J.; Santisteban-Arenas, R.; Hoyos-Jaramillo, A.; Estevez-Varon, J.V.; Fontúrbel, F.E. Foraging behavioural traits of tropical insectivorous birds lead to dissimilar communities in contrasting forest habitats. Wildl. Biol. 2019, 2019 , wlb-00483. [CrossRef]

31. Betancurt-Grisales, J.F.; Vargas-Daza, A.M.; Castaño-Villa, G.J.; Ospina-Bautista, F. Bird functional diversity in restored and secondary forests of the Colombian Andes. Restor. Ecol. 2021, 29, e13315. [CrossRef]

32. Fierro-Calderón, E.; Eusse, D. Estado de Conocimiento de las Aves en el Departamento de Caldas: Prioridades de Conservación y Vacíos de Información; Asociación Calidris: Cali, Colombia, 2010.

33. Castaño, J.H.; Corrales, J.D. Mamíferos de la cuenca del río La Miel (Caldas): Diversidad y uso cultural. Boletín Científico. Cent. De Museos. Mus. De Hist. Nat. 2010, 14, 56-75.

34. Bregman, T.P.; Lees, A.C.; MacGregor, H.E.; Darski, B.; de Moura, N.G.; Aleixo, A.; Barlow, J.; Tobias, J.A. Using avian functional traits to assess the impact of land-cover change on ecosystem processes linked to resilience in tropical forests. Proc. R. Soc. B Biol. Sci. 2016, 283, 20161289. [CrossRef] [PubMed]

35. Arcila, J.; Farfán, F.; Moreno, A.; Salazar, L.F.; Hincapié, E. Sistemas de Producción de Café en Colombia; CENICAFE: Manizales, Colombia, 2007.

36. Martínez-Sánchez, E.T.; Cardona-Romero, M.; Rivera-Páez, F.A.; Pérez-Cárdenas, J.E.; Castaño-Villa, G.J. Contribution of agroecosystems to the conservation of bird diversity in the department of Caldas. Rev. Fac. Nac. De Agron. Medellín 2018, 71, 8445-8457. [CrossRef]

37. IDEAM. Promedios de Precipitación y Temperatura Media. Promedio de Los Años 1981-2010; IDEAM: Bogotá, Colombia, 2017. Available online: https:/ / www.datos.gov.co/Ambiente-y-Desarrollo-Sostenible/Promedios-Precipitaci-n-y-Temperatura-mediaPromed/nsxu-h2dh/data (accessed on 8 May 2021).

38. Blake, J.G.; Loiselle, B.A. Bird assemblages in second-growth and old-growth forests, Costa Rica: Perspectives from mist nets and point counts. Auk 2001, 118, 304-326. [CrossRef]

39. Faria, D.; Laps, R.R.; Baumgarten, J.; Cetra, M. Bat and bird assemblages from forests and shade cacao plantations in two contrasting landscapes in the Atlantic Forest of southern Bahia, Brazil. Biodivers. Conserv. 2006, 15, 587-612. [CrossRef]

40. Karr, J.R. Surveying birds with mist nets. Stud. Avian Biol. 1981, 6, 62-67.

41. Dunn, E.H.; Ralph, C.J. The use of mist nets as a tool for bird population monitoring. Stud. Avian Biol. $2004,29,1-6$.

42. Remsen, J.; Areta, J.; Bonaccorso, E.; Claramunt, S.; Jaramillo, A.; Pacheco, J.; Ribas, C.; Robbins, M.; Stiles, F.; Stotz, D. A Classification of the Bird Species of South America; American Ornithological Society: Chicago, IL, USA, 2020.

43. Luck, G.W.; Lavorel, S.; McIntyre, S.; Lumb, K. Improving the application of vertebrate trait-based frameworks to the study of ecosystem services. J. Anim. Ecol. 2012, 81, 1065-1076. [CrossRef]

44. Cardona-Salazar, L.J.; Benavides-Ossa, Y.A.; Vargas-Daza, A.M.; Betancurt-Grisales, J.F.; Bohada-Murillo, M.; Martinez-Sanchez, E.T.; Cardona-Romero, M.; Busi, A.; Tobon-Escobar, W.D.; Ortiz-Giraldo, M.; et al. A morphological, reproductive, and molt phenology database for 379 bird species from the Colombian Tropical Andes. Ecology 2020, 101, e03016. [CrossRef] [PubMed]

45. Hilty, S.L.; Brown, W.L.; Brown, B. A Guide to the Birds of Colombia; Princeton University Press: Princeton, NJ, USA, 1986.

46. Del Hoyo, J.; Elliott, A.; Christie, D. Handbook of Birds of the World; Lynx edicions: Barcelona, Spain, 1992.

47. Legendre, P.; Legendre, L. Numerical Ecology; Elsevier: Oxford, UK, 2012.

48. Pillar, V.D.; Duarte, L.D.S. A framework for metacommunity analysis of phylogenetic structure. Ecol. Lett. 2010, 13, 587-596. [CrossRef] [PubMed]

49. Pillar, V.D.; Duarte, L.d.S.; Sosinski, E.E.; Joner, F. Discriminating trait-convergence and trait-divergence assembly patterns in ecological community gradients. J. Veg. Sci. 2009, 20, 334-348. [CrossRef]

50. Botta-Dukát, Z. Rao's quadratic entropy as a measure of functional diversity based on multiple traits. J. Veg. Sci. 2005, 16, 533-540. [CrossRef]

51. Mason, N.W.; Mouillot, D.; Lee, W.G.; Wilson, J.B. Functional richness, functional evenness and functional divergence: The primary components of functional diversity. Oikos 2005, 111, 112-118. [CrossRef]

52. Cosset, C.C.; Edwards, D.P. The effects of restoring logged tropical forests on avian phylogenetic and functional diversity. Ecol. Appl. 2017, 27, 1932-1945. [CrossRef] [PubMed]

53. Schaaf, A.A.; Gomez, D.; Ruggera, R.A.; Tallei, E.; Vivanco, C.G.; Politi, N.; Rivera, L. Functional diversity of tree cavities for secondary cavity-nesting birds in logged subtropical Piedmont forests of the Andes. For. Ecol. Manag. 2020, $464,118069$. [CrossRef]

54. Laliberté, E.; Legendre, P.; Shipley, B.; Laliberté, M.E. Package 'FD'. Measuring Functional Diversity from Multiple Traits, and Other Tools for Functional Ecology, Version 1.0; CRAN, 2014.

55. R Development Core Team. R: A language and Environment for Statistical Computing, Reference Index, Version 3.6.1; Foundation for Statistical Computing: Vienna, Austria, 2019.

56. Box, G.E.; Cox, D.R. An analysis of transformations. J. R. Stat. Soc. Ser. B Methodol. 1964, 26, 211-243. [CrossRef] 
57. Bates, D.; Maechler, M.; Bolker, B. lme4: Linear Mixed-Effects Models Using S4 Classes. R Package Version 0.999375-39. Available online: http: / /CRAN.R-project.org/package=lme4 (accessed on 8 May 2021).

58. Wickham, H. ggplot2: Elegant Graphics for Data Analysis; Springer: New York, NY, USA, 2016.

59. Debastiani, V. Package "SYNCSA": Analysis of Functional and Phylogenetic Patterns in Metacommunities, R Package; CRAN, 2018.

60. Morelli, F.; Benedetti, Y.; Perna, P.; Santolini, R. Associations among taxonomic diversity, functional diversity and evolutionary distinctiveness vary among environments. Ecol. Indic. 2018, 88, 8-16. [CrossRef]

61. Solé-Senan, X.; Juárez-Escario, A.; Robleño, I.; Conesa, J.; Recasens, J. Using the response-effect trait framework to disentangle the effects of agricultural intensification on the provision of ecosystem services by Mediterranean arable plants. Agric. Ecosyst. Environ. 2017, 247, 255-264. [CrossRef]

62. Alexander, J.; Smith, D.A.E.; Smith, Y.C.E.; Downs, C.T. Drivers of fine-scale avian functional diversity with changing land use: An assessment of the effects of eco-estate housing development and management. Landsc. Ecol. 2019, 34, 537-549. [CrossRef]

63. Cabrera, O.; Hildebrandt, P.; Stimm, B.; Günter, S.; Fries, A.; Mosandl, R. Functional Diversity Changes after Selective Thinning in a Tropical Mountain Forest in Southern Ecuador. Diversity 2020, 12, 256. [CrossRef]

64. Makumbe, P.; Chikorowondo, G.; Dzamara, P.C.; Ndaimani, H.; Gandiwa, E. Effects of Fire Frequency on Woody Plant Composition and Functional Traits in a Wet Savanna Ecosystem. Int. J. Ecol. 2020, 2020, 1672306. [CrossRef]

65. Tsianou, M.A.; Kallimanis, A.S. Trait selection matters! A study on European amphibian functional diversity patterns. Ecol. Res. 2019, 34, 225-234. [CrossRef]

66. Villéger, S.; Miranda, J.R.; Hernández, D.F.; Mouillot, D. Contrasting changes in taxonomic vs. functional diversity of tropical fish communities after habitat degradation. Ecol. Appl. 2010, 20, 1512-1522. [CrossRef]

67. Tscharntke, T.; Sekercioglu, C.H.; Dietsch, T.V.; Sodhi, N.S.; Hoehn, P.; Tylianakis, J.M. Landscape constraints on functional diversity of birds and insects in tropical agroecosystems. Ecology 2008, 89, 944-951. [CrossRef]

68. Rocha, J.; Laps, R.R.; Machado, C.G.; Campiolo, S. The conservation value of cacao agroforestry for bird functional diversity in tropical agricultural landscapes. Ecol. Evol. 2019, 9, 7903-7913. [CrossRef]

69. Gliessman, S.R.; Guadarrama-Zugasti, C.; Mendez, V.E.; Trujillo, L.; Bacon, C.; Cohen, R. Agroecología: Un enfoque sustentable de la agricultura ecológica. In ¿Qué Es La Agroecología? Universidad Complutense de Madrid: Madrid, Spain, 2006.

70. Edwards, F.A.; Edwards, D.P.; Larsen, T.H.; Hsu, W.W.; Benedick, S.; Chung, A.; Vun Khen, C.; Wilcove, D.S.; Hamer, K.C. Does logging and forest conversion to oil palm agriculture alter functional diversity in a biodiversity hotspot? Anim. Conserv. 2014, 17, 163-173. [CrossRef] [PubMed]

71. Davies, R.; Edwards, D.; Edwards, F. Secondary tropical forests recover dung beetle functional diversity and trait composition. Anim. Conserv. 2020, 23, 617-627. [CrossRef]

72. Villéger, S.; Mason, N.W.; Mouillot, D. New multidimensional functional diversity indices for a multifaceted framework in functional ecology. Ecology 2008, 89, 2290-2301. [CrossRef] [PubMed]

73. Borkhataria, R.R.; Collazo, J.A.; Groom, M.J. Additive effects of vertebrate predators on insects in a Puerto Rican coffee plantation. Ecol. Appl. 2006, 16, 696-703. [CrossRef]

74. Borkhataria, R.R.; Collazo, J.A.; Groom, M.J. Species abundance and potential biological control services in shade vs. sun coffee in Puerto Rico. Agric. Ecosyst. Environ. 2012, 151, 1-5. [CrossRef]

75. García-Navas, V.; Thuiller, W. Farmland bird assemblages exhibit higher functional and phylogenetic diversity than forest assemblages in France. J. Biogeogr. 2020, 47, 2392-2404. [CrossRef]

76. MacArthur, R.H.; MacArthur, J.W. On bird species diversity. Ecology 1961, 42, 594-598. [CrossRef]

77. Tews, J.; Brose, U.; Grimm, V.; Tielbörger, K.; Wichmann, M.C.; Schwager, M.; Jeltsch, F. Animal species diversity driven by habitat heterogeneity/diversity: The importance of keystone structures. J. Biogeogr. 2004, 31, 79-92. [CrossRef]

78. Jessel, H.R.; Aharoni, L.; Efroni, S.; Bachelet, I. A modeling algorithm for exploring the architecture and construction of bird nests. Sci. Rep. 2019, 9, 14772. [CrossRef] [PubMed]

79. Bellamy, P.E.; Burgess, M.D.; Mallord, J.W.; Cristinacce, A.; Orsman, C.J.; Davis, T.; Grice, P.V.; Charman, E.C. Nest predation and the influence of habitat structure on nest predation of Wood Warbler Phylloscopus sibilatrix, a ground-nesting forest passerine. $J$. Ornithol. 2018, 159, 493-506. [CrossRef]

80. Johnson, R.J.; Jedlicka, J.A.; Quinn, J.E.; Brandle, J.R. Global perspectives on birds in agricultural landscapes. In Integrating Agriculture, Conservation and Ecotourism: Examples from the Field; Springer: Berlin/Heidelberg, Germany, 2011. [CrossRef]

81. Navalón, G.; Bright, J.A.; Marugán-Lobón, J.; Rayfield, E.J. The evolutionary relationship among beak shape, mechanical advantage, and feeding ecology in modern birds. Evolution 2019, 73, 422-435. [CrossRef] [PubMed]

82. Bommarco, R.; Kleijn, D.; Potts, S.G. Ecological intensification: Harnessing ecosystem services for food security. Trends Ecol. Evol. 2013, 28, 230-238. [CrossRef]

83. Kleijn, D.; Bommarco, R.; Fijen, T.P.M.; Garibaldi, L.A.; Potts, S.G.; van der Putten, W.H. Ecological intensification: Bridging the gap between science and practice. Trends Ecol. Evol. 2019, 34, 154-166. [CrossRef]

84. Tittonell, P. Ecological intensification of agriculture-Sustainable by nature. Curr. Opin. Environ. Sust. 2014, 8, 53-61. [CrossRef] 